\title{
"Don't think, but look!": W. G. Sebald, Wittgenstein, and Cosmopolitan Poverty
}

\author{
Like a dog \\ Cézanne says \\ That's how a painter \\ must see, the eye \\ fixed $\mathcal{E}$ almost \\ averted \\ -W. G. Sebald ${ }^{1}$
}

\begin{abstract}
SEbALD's IS AN UNCANNY UNIVERSE where historical fact and documentary media-photographs, memorabilia, and newspaper clippingsmingle with, and at times interpenetrate, fictive invention to create artifices of authenticity. And propelling each of his four hybrid narratives are the peregrinations across Europe of a solitary, nameless narrator, often suffering in body and mind. His restless tacking, at once urgent but motiveless, complements and conditions his associative ruminations, both feeding on "scraps of memory," which in turn disclose webs of historical and personal coincidence, "all interlocking like ... labyrinthine vaults." ${ }^{2}$ But such encounters with the "ghosts of repetition"-embedded and layered traces of the past in the present-in their surreal and hallucinatory strangeness often leave him dizzy and unnerved. ${ }^{3}$ Something of this affect is imparted to Sebald's readers who are denied the snug pleasure of being comfortably absorbed in a plot. Rather, we are made to accompany a narrator whose principal activity as he travels is assembling notes and weaving the palimpsests that constitute the form and matter of Sebald's books. Drawing from his apparently limitless fund of obscure detail and miscellaneous learning, including the history of silk weaving, Sebald makes paramount the very act of patterning, as if his commitment is less to content than to relationality itself as a structural principle whose
\end{abstract}

ABSTRACT This essay has two aims: to bring together the antinovelist Sebald with a figure he revered, the antiphilosopher Wittgenstein, via the theme and form of "desublimed" looking—vision that respects surface and avoids "Cartesian rigidity" (Sebald). The essay weaves these two writers into a larger constellation, inaugurated by the first cosmopolitan Diogenes the Cynic, and which includes his admirer William James, a grouping marked by an esteem of poverty and the desire to find an exit from the refinement of philosophy as metaphysics. / Representations 112. Fall 2010 () The Regents of the University of California. ISSN 0734-6018, electronic ISSN 1533-855X, pages 112-139. All rights reserved. Direct requests for permission to photocopy or reproduce article content to the University of California Press at http://www. ucpressjournals.com/reprintinfo.asp. DOI:10.1525/rep.2010.112.1.112.

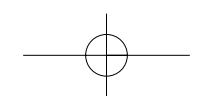


description we might borrow from Ludwig Wittgenstein's famous evocation of "family resemblance."

This mode of likeness is founded not on essence or identity, the philosopher tells us in The Philosophical Investigations, but is "a complicated network of similarities overlapping and crisscrossing: sometimes overall similarities, sometimes similarities of detail"; we extend our concept "as in spinning a thread we twist fibre on fibre," the fiber's strength residing "in the overlapping of many fibres." These images of tensile density and energy are themselves threads that overlap with others, specifically his prefatory description of the form of his investigations: he confesses that he has composed not a unified, systematic treatise but an "album" of "remarks" that refuses to cohere into "any single direction." Instead they follow their "natural inclination," compelling "us to travel over a wide field of thought criss-cross in every direction." Composing his text was akin to dashing off "sketches of landscapes" during "long and involved journeyings" ( $P I, \mathrm{v})$. Neither attaining perfect clarity nor finding a secure home were ever considerations.

By the preface's end Wittgenstein speaks of "the lot of this work, in its poverty and in the darkness of this time" (1945), "poverty" being perhaps a gnomic nod to his book's dispersed, improvised formal structure enacting uprooting amid "darkness"- the upheaval of the Second World War (vi). (The pessimistic Oswald Spengler was one of Wittgenstein's favorites.) It is only a small exaggeration to say that these well-known prefatory passages, where thinking and writing are at one with the "poverty" of meandering motion amid a world out of joint, might have come from Sebald's pen, so apt are they in imparting his world-its bleak emotional textures and ceaseless movements of an afflicted creature. Each man was an émigré, one from Vienna, one from Bavaria, and each gained fame in England while continuing to write in German. Working from within to lighten the formal heaviness of conventional modes of philosophy and novels (Sebald, for instance, scorned the "clumsy machinery" of "heavily plotted novels" and his narrators, for all their angst, are without psychic depth), both turn cosmopolitanism toward its Greek origins. ${ }^{5}$ These origins are less in class privilege than in the rhythms of creaturely and visceral experience, in elected poverty, perpetual journeys, and willed homelessness. Wittgenstein and Sebald let philosophic thought and literary form take the impress of our animal body in motion and do so without embracing a by now banal primitivism with its inevitable quest for authenticity.

If, for most critics, the saturnine Walter Benjamin figures as the "patron saint" of Sebald's literary universe, as Eric Santner has recently remarked and reaffirmed, my aim here is to see what happens when we let Wittgenstein play that role. ${ }^{6}$ I mean the late Wittgenstein who in Philosophical Investigations and On Certainty rejects the priority in modern culture of philosophy as epistemology and treats man as a "creature in a primitive state," guided more by

“Don't think, but look!": W. G. Sebald, Wittgenstein, and Cosmopolitan Poverty

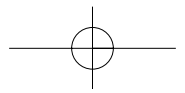


animal instinct than by reason. ${ }^{7}$ Sebald admitted to a fascination with Wittgenstein, once even drafting a film script of his life, and saluted him in The Emigrants and Austerlitz. ${ }^{8}$ In the former book Max Ferber, the painter whose life story is recounted in the last chapter, recalls that in 1944 he had roomed in the same house where Ludwig Wittgenstein had lived in 1908. Ferber savors the coincidence, for it makes him feel "as if he were tightening his ties to those who had gone before." He is "aware of a sense of brotherhood that reached far back beyond his own lifetime." "This brief passage from The Emigrants — both in its particular allusion to Wittgenstein and implied larger sense of the past as a transhistorical "brotherhood" or intricate tapestry of "ties"inspires my effort to forego the chronology of a genealogy for the more synchronic form of a constellation that threads the antinovelist Sebald and the antiphilosopher Wittgenstein into the weave of a "family resemblance."

But constellation is not sufficiently precise to describe my particular practice of reading here. Informing that practice is the thinking of another German émigré, Wittgenstein's junior by fourteen years, Theodor Adorno, who in the wake of the destruction of the Second World War declared the very notion of "house" to be passé and remarked that it is "part of morality not to be at home in one's home." 10 This acceptance of deracination implicitly conditions Adorno's preference for philosophical texts that are unanchored to argument. "The ideal is nonargumentative thought" that does not lead the reader on an "intellectual forced march" demanding disciplined focus, but rather works by "implied meanings" conceived as "inherently in motion." Miming this motion, the reader is "to float along" in a state of receptivity that Adorno describes as a "relaxed" or associative approach to the text. "Relaxation of consciousness as an approach means not warding off associations but opening the understanding to them.... At every point one must try to admit as many possibilities for what is meant, as many connections to something else, as may arise. A major part of the work of the productive imagination consists in this." Such openness to connections "shakes off the automatic discipline that is required for pure concentration on the object and that thereby

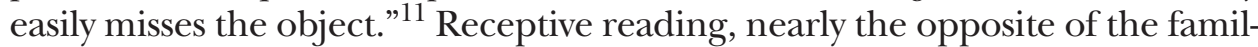
iar postmodern adversarial relation of critic to text, is guided by a mimetic sympathy toward its object. What results in this essay will be a broad associative weave of linkages and also an intimacy between my critical method and my peripatetic principal figures Wittgenstein and Sebald. The method and authors both produce a network of overlapping relations that I name with the somewhat oxymoronic phrase "cosmopolitan poverty" and it includes another anti-capital $P$ Philosopher, William James.

Wittgenstein warmly admired the James of The Varieties of Religious Experience, with its esteem for asceticism and "poverty." Wittgenstein disliked pragmatist philosophy (and never read James's Pragmatism), which he equated

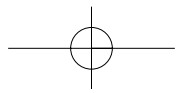


with an ideology of scientism and progressivism; but he once grudgingly acknowledged that, though this "Weltanschauung" made him feel "thwarted," "I am trying to say something that sounds like pragmatism" $(O C, \# 422) .{ }^{12}$ Although he never elaborated, we can fill in this remark by noting their shared rejection of theoretical explanation and stress on doing without knowing, both emphases helping to shut down what John Dewey derided as the "epistemology industry" that had been synonymous with capital PPhilosophy since Descartes. What brings together Wittgenstein's respect for James's praise of poverty with his admittedly wary sense of affinity with pragmatism is an investment in denial: of material comforts and of what James calls the "refinements" of philosophy. The former denial is the impoverishment he chooses, the latter denial the impoverishment he rejects.

A passage from Sebald can help here. Sebald seeks to elude what he calls "Cartesian rigidity," for its reductive rationalism constitutes, in his Foucaultflavored phrase, "one of the principal chapters in the history of subjection." Descartes teaches "that one should disregard the flesh, which is beyond our comprehension, and attend to the machine within, to what can be fully understood, be made wholly useful for work" $(R S, 13)$. To dismiss the sensory and make the world an object of instrumental knowledge counts as a cardinal instance of what James early in Pragmatism calls the "refinement that characterizes our intellectualist philosophies" with their "craving for a refined object of contemplation." ${ }^{33}$ Such refinement, in short, is a refining away, an impoverishment. The purification implicit in Descartes's theorizing of a disembodied Godlike gaze, enshrined in the Enlightenment and modernity, would both inform and incite the counterresponse of modernism across the arts. ${ }^{14}$

Modern painting's high priest of Cartesian formalist purity was Clement Greenberg. At least that is the role he plays for Rosalind Krauss, whose postmodern rewriting of twentieth-century art history works against the modernist grain of "optical autonomy" and would return "sight to its seat in the affective, erotic ground of the body." 15 By considering the terms in which she describes Greenberg's "mission" we will sharpen the contrast with my principal figures. Krauss's specific target is what she calls Greenberg's "sublimating" or making vertical of Jackson Pollock,

of raising him from that dissolute squat ... slouched over his paintings in the disarray of his studio. ... This is the posture, in all its lowness, projected by so many famous photographs, ... the dark brooding silence of the stilled body, with its determined isolation from everything urban, everything "cultured." The photographs had placed him on the road, like Kerouac, clenching his face into the tight fist of beat refusal, making an art of violence, of "howl." Clem's mission was to lift him above those pictures, just as it was to lift the paintings Pollock made from off the ground where he'd made them, and onto the wall . . . the full redemptive gesture, the raising of the work from off its knees and onto the grace of the wall in one

“Don't think, but look!": W. G. Sebald, Wittgenstein, and Cosmopolitan Poverty

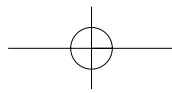


unbroken benediction, the denial of wild heedlessness in order to clear a space for the look, the look that will (in its very act of looking) create order, and thus create painting-_sophisticated" painting. . . . To stand upright is to attain to a peculiar form of vision: the optical; and to gain this vision is to sublimate, to raise up, to purify."16

In bringing Pollock down to the ground, Krauss's hymn to the horizontal becomes tantamount to enrolling him in the fifties' pantheon of ecstatic American outlaw visionaries, paragons of primitive authenticity who are all avatars of Huck Finn, notoriously finicky “'bout bein' sivilize[d]." Krauss's Pollock is gloriously guilty of the "culture crime of desublimation," which is how Philip Roth has Nathan Zuckerman describe the offense he committed in writing his scandalous bestseller Carnovsky (read Portnoy's Complaint). ${ }^{17}$ In America, the "culture crime of desublimation" is our most familiar and cherished artistic mythology, shot full of artificial preservatives to retain its excitingly raw flavor. While the fervency of Krauss's rescue of Pollock makes this mythology hard to resist, one should try, if only to be open to less romantic but subtler modes of "the culture crime of desublimation."18

Wittgenstein, for instance, is clearly invested in desublimation and in toppling the vertical pillars of philosophy. He favors sublime as a verb-to sublime is to purify, and once logic is sublimed it makes philosophy metaphysical speculation rather than investigation of the concrete. He is devoted to undoing or thwarting this subliming urge that sends us "in pursuit of chimeras"; his aim is to desublime $(P I, 94)$. While this desublimation radically, startlingly, reorients capital $P$ Philosophy, Wittgenstein's axial rotation has little to do with the scenario that Krauss constructs- the redemptive benediction of high culture versus the animal vitality of lowness, in other words, the stark options between the vertical or horizontal. This melodrama has no place for the mix of both postures and planes, a mix discernible for instance in late Wittgenstein's famous "given"- that "forms of life" (as opposed to abstract systems) are "what has to be accepted" (PI, 226). With its biological stress (on "life") and conventional stress (on "forms"), "forms of life," notes Stanley Cavell, is a phrase that enacts the "mutual absorption of the natural and the social."19

The mutual absorption of high and low (whether inflected as vertical and horizontal, cultural and natural) rather than the liberating trumping of the latter over the former, finds its own version in Sebald. ${ }^{20}$ The narrator's relentless collecting of knowledge, often antiquarian in its appetite for minutiae, would seem to confine him to a Casaubon-like imprisonment in the mind. But the claims of his own vulnerable body are always intruding, registered in his marked attunement to animals: wandering aimlessly in Vienna, on the verge of collapse, the narrator of Vertigo confesses that the only creatures he talks to are the jackdaws and blackbirds in the city gardens. And at the start of Austerlitz

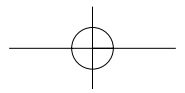


a similarly distressed narrator takes refuge in a zoo. To these characteristic Sebaldian moments we can name another-his merging of animal and human by embedding them within a literary allusion: the narrator at the start of The Rings of Saturn describes how, like Franz Kafka's Gregor Samsa with his "dimmed eyes," "half on my belly and half sideways," he drags himself up to the window to gaze out at the "twilit hour" when the familiar is "utterly alien" (5).

While acknowledging the vertical, my stress will be on the gravitational pull of the horizontal, as expressed in Sebald's and Wittgenstein's desubliming of vision that turns it into a kind of looking that is free of "Cartesian rigidity." But this is not to ascribe to desublimed looking a specific, single content and form. For Wittgenstein especially, what constitutes looking is neither fixed nor a priori, since his aim is to avoid constructing a global theoretical framework. Such grand ambitions, relying on generalizing explanation and identity that prefer the clear and distinct, have no patience for different cases and contexts that ask for particular kinds of looking. And those who pursue grand theoretical ambitions turn into static figures-as spokesmen or representatives of a Weltanschauung. But "the philosopher is not a citizen of any community of ideas. This is what makes him into a philosopher."21 In philosophizing, Wittgenstein remarks, "it is important to keep changing" one's "posture, not to stand for too long on one leg, so as not to get stiff." ${ }^{22}$ Striking here is how Wittgenstein's desubliming of philosophy embodies a physical suppleness that finds its complement in his cosmopolitan deracination. What he offers instead of a rooted, identifiable perspective is a heuristic, a way to get on that suggests "how to see things, not the way one ought to see them." ${ }^{23}$ For both authors, how to see things is "tangled" (the philosopher's word) for it involves tentative, revisable glimpses of approximate connections as well as differences-the rough "family resemblances" of overlap—rather than vision rigidly focused on seizing (an alleged) inner essence, on folding the outward into the inward, ignoring the fleshly surface in a rush to espy the "machine within."

Critiquing the shrunken subjectivity of the Cartesian legacy inspires in each writer a flight from the metaphysics of philosophic "refinement" and toward affiliation with the "natural history" (Wittgenstein) we share with the animal, a sense of kinship that is drawn to horizontality but not to wallow in or celebrate it as the exhilarating negation of culture. These figures of cosmopolitan poverty move downward. "Anything I might reach by climbing a ladder does not interest me," remarks the philosopher $(C V, 7)$. We live not on the slippery ice of "crystalline purity" that only philosophy imagines to exist but—and where else could we live-on the "friction" of the "rough ground" of the ordinary where vision routinely risks indistinction. "What's ragged should be left ragged" $(C V, 45)$. And here on the rough ground "since everything lies open to view there is nothing to explain" $(P I, 107,126)$. Sebald and Wittgenstein, and William James, each takes his own route down and the

“Don't think, but look!": W. G. Sebald, Wittgenstein, and Cosmopolitan Poverty

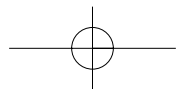


catalysts earthward are various: experience (James), the ordinary (Wittgenstein), and melancholy (Sebald). ${ }^{24}$

Early in Austerlitz we find Sebald weaving Wittgenstein into his tapestry. The philosopher enters the novel by name thanks to the fact that the title character, a late twentieth-century London-based architectural historian of late nineteenth-century Europe, has a rucksack always slung over his shoulder. Upon announcing this, Sebald's nameless narrator then inserts a picture of one into the text, apparently to memorialize a "rather outlandish idea": that the character Austerlitz and Wittgenstein possess a personal and physical similarity. With his characteristic eye for "family resemblance" that blurs the firmly discrete, the narrator notes: "Whenever I see a photograph of Wittgenstein ... I feel more and more as if Austerlitz were gazing at me out of it, and when I look at Austerlitz it is as if I see in him the disconsolate philosopher." What they share is a "horror-stricken" expression, a detached air of scrutiny, as well as "the makeshift organization of their lives," the "wish to manage with as few possessions as possible," and an abruptness in addressan "inability to linger over any kind of preliminaries" (41).

Even prior to this explicit mention, Wittgenstein is a physical presence in Austerlitz. He stares at us from the novel's third page (fig. 1), which features a pair of unidentified photographs tightly focused on the penetrating gazes of two men. The lower is Wittgenstein, the upper is the artist and Sebald collaborator Jan Peter Tripp, whose hyperrealist lithographs of pairs of eyes are collected with Sebald's micropoems (see my epigraph) in the posthumously published Unrecounted (2003). Sebald groups Tripp and Wittgenstein-obsessive masters of looking at looking-with two close-ups of the enormous eyes of what appear to be a bat (the top image) and an owl (the image below it).$^{25}$ Commenting on these denizens of the "Nocturama" he has been observing, the narrator says: "Several of them had strikingly large eyes, and the fixed, inquiring gaze found in certain painters and philosophers who seek to penetrate the darkness which surrounds us purely by means of looking and thinking" $(A, 4-5)$. "Darkness" nods to Wittgenstein's use of the word in the preface to Philosophical Investigations. Sebald conjoins animal and philosopher and artist in wordless alliance, a shared keenness of ocular intensity.

When read together, these two invocations of Wittgenstein-knapsack and eyes, ascetic wanderer with a gaze of animal fixity-disclose an antecedent presence unmentioned but unmistakable, Diogenes the Cynic, the first selfdescribed cosmopolitan. He will be another strand in my constellation. The vagrant Diogenes, the fifth century BCE Athenian troublemaker, was famous for scorning all pieties. On antagonistic terms with philosophy, he anticipates with gaudy literalism the conjunction in James and Wittgenstein between esteem of poverty and the desire to find an exit from the "refinement" of

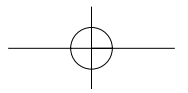


apple over and over again, as if it hoped that all this washing, which went far beyond any reasonable thoroughness, would help it to escape the unreal world in which it had arrived, so to speak, through no fault of its own. Otherwise, all I remember of the denizens of the Nocturama is that several of them had strikingly large eyes, and the fixed,
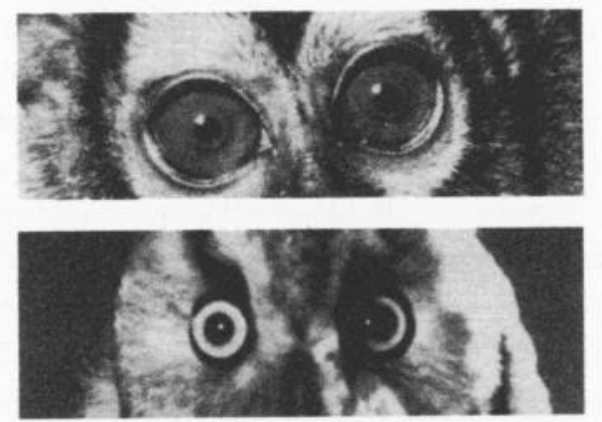

inquiring gaze found in certain painters and philosophers who seek to penetrate the darkness

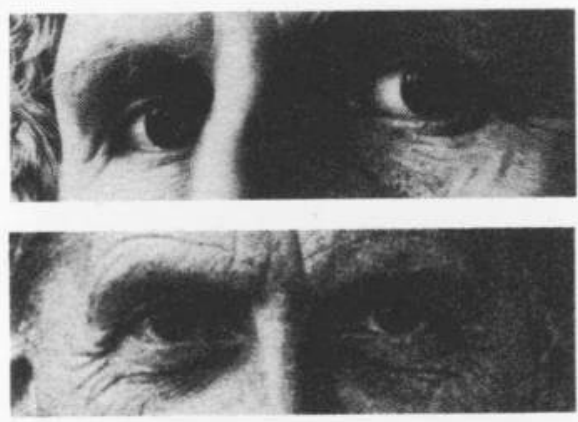

which surrounds us purely by means of looking and thinking. I believe that my mind also dwelt on

$$
-3-
$$

FIGURE 1. Images from Austerlitz by W. G. Sebald. Used with permission of The Wylie Agency LLC on behalf of the Estate of W. G. Sebald.

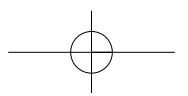


philosophy as metaphysics. Giving bite to the etymology of cynic as the dog (kuon), a creature immune to shame, Diogenes has a programmatic commitment to outrageous acts that mock the Greek esteem for rational thought and turn private behavior public by masturbating, defecating, and urinating in the town square. Here we might say is the primal scene of the "culture crime of desublimation." Diogenes' aggressive naturalism regarded "canons of decency" as "artificial and thus irrational" so he scorned material comfort and sought to perfect through rigorous discipline a wholly natural self-sufficiency. ${ }^{26}$ With all his worldly possessions kept in a knapsack, Diogenes combined animal excess with an ascetic refusal of comfort and routine. William James's airbrushed late Victorian version of Diogenes saluted him for possessing the pragmatist spirit of anarchic insouciance and the Cynic, a touchstone for freethinkers throughout the eighteenth and nineteenth centuries, can with some justice be regarded as the progenitor of all deracinated iconoclasts, including the pair of ascetic, itinerant, melancholy intellectuals Wittgenstein and Sebald.

"Don't think, but look!" Coming from a philosopher this is a strange command. And it announces an uncanny aim: "We want to understand something that is already in plain view" (PI, \#89). What obstructs this seemingly simple task is the bias, taught by the method of science, that construes logical thinking as a looking past the surface in search of explanation or essence that is supposed to be "pure and clear-cut," a search "to the bottom of things" founded on an ideal of hiddenness basic to mind/body dualism that posits the privacy of the mental (\#105, \#89). ${ }^{27}$ Rejecting the assumption that "what is internal is hidden from us," Wittgenstein counters: "If I see someone writhing in pain with evident cause I do not think: all the same, his feelings are hidden from me" (PI, 223). "If one sees the behaviour of a living thing, one sees its soul" (PI, \#357). "The human body is the best picture of the human soul" (PI, 178).

The primacy of the body's behavior chimes with Diogenes' histrionic selfexposure as hands-on mockery of the metaphysical abstractions his philosophical colleagues pursued. When Zeno "declared there was no such thing as motion, he got up and walked about." ${ }^{28}$ Something of the Cynic's scoffing finds compressed expression in "Don't think, but look!" Wittgenstein's own antimetaphysical imperative refuses to "sublime" looking into a practice guided by ideals of transparency or crystalline clarity. "How completely ragged what we see can appear!" (PI, 200). William James in The Principles of Psychology (a book Wittgenstein read and repeatedly discusses) famously urged a "reinstatement of the vague" to "its proper place in our mental life" as one way of "exploding the ridiculous theory of Hume and Berkeley that we can have no images but of perfectly definite things. . . . The definite images of traditional psychology form but the very smallest part of our minds as they

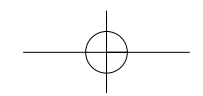


actually live." Rather, every image is "steeped and dyed" in the flow of consciousness, imbuing the image with a "fringe" or "halo of relations." ${ }^{29}$ Wittgenstein implicitly concurs:

the concept of "seeing" makes a tangled impression. Well, it is tangled. - I look at the landscape, my gaze ranges over it, I see all sorts of distinct and indistinct movement; this impresses itself sharply on me, that is quite hazy. . . But this just is what is called description of what is seen. There is not one genuine proper case of such description - the rest being just vague, something which awaits clarification, or which just must be swept aside as rubbish. Here we are in enormous danger of wanting to make fine distinctions. (PI, 200)

Esteem of the vague orients as well Sebald's selection of many of the photographs he layers into his texts; challenging our assumption that documentary images yield clarity and possess a privileged veracity, the photographs are uncaptioned, uncredited, untethered to source or fact, often blurry or enigmatic or askew; above all they slow down the reader, at once inviting and frustrating and prolonging looking. ${ }^{30}$

To trust what is in front of one's eyes-tangled and ragged impressionsstakes a claim that Diogenes would respect. For this trust acknowledges the force of surface appearance as well as the human "urge to appear" and impulse to display, both of which the Cynic obeys in his emptying out of the private. ${ }^{31}$ And with the private goes the very notion of hiddenness that Wittgenstein critiqued. Diogenes' campaign against the hidden extended to puncturing his colleagues' abstractions. After Plato defined man as "an animal, biped and featherless, and was applauded," Diogenes "plucked a fowl and brought it into the lecture room with the words, "Here is Plato's man"” $(L, 43)$. Diogenes dubbed himself a "Socrates gone mad" $(L, 55)$. Finding capital $P$ Philosophy infected by theoretical speculation, he turned it into spiritual exercise or therapy, a way of life. As a "mode of existing-in-the-world," philosophy sought "wisdom itself. For real wisdom does not merely cause us to know: it makes us 'be' in a different way," says Pierre Hadot. ${ }^{32}$ Hadot has noted that "in antiquity one historian wondered whether Cynicism could be called a philosophical school—whether it mightn't be instead, only a way of life." His therapeutic orientation anticipates Wittgenstein, the subject of Hadot's early work, and a philosopher who described his investigations as a cure for the illness of metaphysical language. ${ }^{33}$ He famously said, "The real discovery is the one that makes me capable of stopping doing philosophy when I want to," and his suspicion of the profession led him to advise his best students away from academic careers (PI, \#133).

When asked where he came from, Diogenes, notorious as the homeless vagabond philosopher wandering the Athenian marketplace, replied "I am a citizen of the world," thereby originating the term "cosmopolitan" $(L, 65)$. Although the word has been ubiquitous in academia for at least a decade and

“Don't think, but look!”: W. G. Sebald, Wittgenstein, and Cosmopolitan Poverty

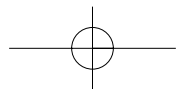


a half, this first use, if mentioned at all, is seldom linked to Diogenes' scandalous behavior. One exception is Martha Nussbaum, who argues that Diogenes' "street theater" tries "to get people to question their prejudices"; as an exile from his native Sinope and not a citizen of Athens, Diogenes shocks us with his "unseemly behavior," says Nussbaum, as a way to invite us to become "philosophic exiles from our own way of life ... asking questions an outsider is likely to ask. . . . Only this critical distance ... makes one a philosopher." 34 This strictly rationalist account of Diogenes is sensible as far as it goes; it chimes with the judgment of Jean le Rond d'Alembert, the eighteenth-century philosophe, who said, "Every age ... stands in need of a Diogenes." 35

American culture surely confirms this. Rude truth-tellers, some cosmopolitan, some not, abound, as Rosalind Krauss's evocation of romantic outlaws made vivid. And each in their distinct way could be said to commit the “culture crime of desublimation." American literature's contemporary Diogenes, Philip Roth, took idealizing myths of the Jew as paragon of pure mind and moral virtue and in Portnoy turned them on their heads. By the end of his complaint, Portnoy has thrown in the towel and gone to the dogs: "Maybe the wisest solution for me is to live on all fours! and leave the rightings of wrongs and the fathering of families to the upright creatures!" ${ }^{36}$ In defying the vertical productions of civilization, the VIA, or "Vertical In Authority" revered by Philip Rieff as the realm of the sacred, Roth joins hands with a distinguished American lineage ready to risk the horizontal, a lineage that includes the aforementioned Jackson Pollock, the Ralph Waldo Emerson who calls for "abandonment," the Walt Whitman who leans and loafs at his ease on the ground, the William James who praises "the right to fling away our life irresponsibly," and the Henry David Thoreau of the opening of "Walking," who wishes to "speak a word for absolute freedom and wildness," "to make an extreme statement ... for there are enough champions of civilization: the minister and the school committee." No wonder that Thoreau by 1854 was dubbed "the Yankee Diogenes" and that both Whitman and William James explicitly saluted the Cynic as a tutelary spirit. ${ }^{37}$

In their brash desublimations, these figures assault norms and conventions in pursuit of that venerable American project-authenticity, the liberating of man's repressed animal nature. Freud speaks of the "organic repression" that replaces the nose with the eye as our primary sense organ upon man's assumption of verticality and optical mastery. The temptation of overthrow, of letting go, is hard to resist, evident implicitly, for instance, even in the usually antiromantic antihumanist Foucault. In his early Madness and Civilization, he called psychosis a state of "inaccessible primitive purity" that challenges Western modernity. ${ }^{38}$ Foucault, like the Americans, is within the logic of the most influential critique of Enlightenment modernity-Max Weber's disenchantment of the world thesis-where man's sovereignty,

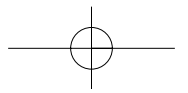


founded on the reduction of rationality to instrumentality enshrined in science, technology, and capital, violently abstracts him from nature. Unnaturally severed from his place in the natural world, the human animal (in subsequent Frankfurt riffs on Weber) masters external nature but at the cost of sacrificing his instinctual vitality, recovery of which is found in the primitive-be it in the form of psychosis or any other candidate elected to serve as the "Other to Reason." Diogenes construed as the emblem of opposition, critique, and iconoclasm - a man whose animal grossness loudly protests the renunciations exacted by society-neatly fits this liberatory paradigm. It is a version of so called "veneer theory," to borrow a phrase of the primatologist Frans de Waal. He rejects "veneer theory," which posits morality as a thin veneer draped over man's brutish nature: "The thinking is thoroughly dualistic: we are part nature, part culture, rather than a well-integrated whole. Human morality is presented as a thin crust underneath which boils antisocial, amoral, and egoistic passions." ${ }^{39}$

But Diogenes as icon of primitivist liberation does not exhaust his meaning; he can also be read in antiveneer fashion, as teaching continuity rather than dualism. His behavior exhibits less the eruption of animal essence than a matter of fact relaxing of conventions that segregate mind from body, private from public, man from animal. ${ }^{40}$ Resisting the model of repression and recovery that builds primitivism into the disenchantment thesis and veneer theory, Wittgenstein and Sebald can be regarded as two of the most creative heirs of Diogenes. For in effect they discern the lesson of his embodied continuity: they depict the nonhuman animal as fellow creature rather than as symbol of man's unalienated freedom. Sebald announces this fellowship by visually juxtaposing owl and philosopher's eyes. Another small example shows this positing of continuum rather than hierarchy: the biographer Diogenes Laertius tells us that Diogenes the Cynic, in "watching a mouse running about ... not looking for a place to lie down in, not afraid of the dark . . . discovered the means of adapting himself to circumstances" (25). Rather than an image of rude truth, of unaccommodated man, the mouse instead models worldly survival strategies for Diogenes.

Continuity between man and animal is the implied point of an early section of Philosophical Investigations that begins by reporting an (allegedly) firm distinction: "It is sometimes said that animals do not talk because they lack the mental capacity. And this means: 'they do not think, and that is why they do not talk.' But they simply do not talk. Or to put it better: they do not use language-if we except the most primitive forms of language.-Commanding, questioning, recounting, chatting, are as much a part of our natural history as walking, eating, drinking, playing” (\#25). This entry proceeds by a series of statements that are then subjected to unsettling qualifications: the firm initial distinctions—between talking and thinking, man and animal—are

“Don't think, but look!": W. G. Sebald, Wittgenstein, and Cosmopolitan Poverty

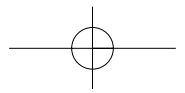


gradually eroded; even the hard-won claim—animals "simply do not talk" — is then qualified: "they do not use language" which, in turn, is revised-they evidently use "the most primitive forms of language." This qualification, Roy Harris notes, "added almost as an afterthought, is of some significance. . . . It seems to indicate a readiness to concede that language is not sharply demarcated from non-linguistic behavior." ${ }^{11}$ And in his concluding list of gerunds Wittgenstein also blurs the sharp distinction between animal and human. None of the actions, save perhaps for "recounting" with its more complicated form of life, are exclusively human but rather are "primitive" practices shared, in their own way, by man and animal. "Our natural history" turns out to include animals: man is not the sole measure of natural history.

Wittgenstein also troubles the oppositions between modern, enlightened man and primitives. He rejects J. G. Frazer's portrayal of primitive people as ruled by irrational beliefs categorically inferior to our own. In rebutting the smug rationalism he found in Frazer's Golden Bough where the magical and religious views and behavior of primitive peoples are regarded as stupid, occupying a lower rung on the upward climb to enlightened reason, Wittgenstein links Frazer's condescension to his commitment to explanation: "The very idea of wanting to explain a practice-for example, the killing of the priestking-seems wrong to me. All that Frazer does is to make them plausible to people who think as he does. . . Here one can only describe and say: this is what human life is like." ${ }^{42}$ Unlike Frazer, whose historical progressivism relegates the primitive to the darkness of unreason, Wittgenstein says that "one could very easily invent primitive practices oneself" because "man is a ceremonial animal" not an exclusively rational being $(127,129)$.

Pragmatism enacts an analogous capaciousness; its naturalist, antiessentialist, Darwinist orientation takes as a given that we struggle to survive and prosper as creatures of "body-mind" (to use Dewey's phrase, which was meant to suggest continuity rather than dualism), a unity of feeling and thinking that is immersed in an ongoing evolutionary process of adaptation to various environments. ${ }^{43}$ This naturalist perspective tends to be lost from contemporary view, displaced by Richard Rorty's influential "linguistic transcendentalism" (Frank Ankersmit's phrase): the belief that human beings are simply the vocabularies they possess. He regards the very notion of prelinguistic experience, with the exception of pain, as absurd. But Rorty's is a perversely intellectualist reading of pragmatism. ${ }^{44}$ William James, after all, regards us as vulnerable, plunging creatures who "like fishes swimming in the sea of sense" live in the "water" of "sensible facts" while "bounded above by the superior element" - abstract ideas-"but unable to breathe it pure or penetrate it" ( WJ, 541).

James wants philosophy to renounce its grander ambitions and "simply feel the detail of things," a stance that anticipates Wittgenstein's own abandonment

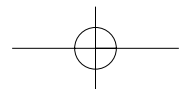


of capital $P$ Philosophy with its impossible demands for precision founded on the "subliming," the idealization, of logic apart from practice (PI,\#94). Early in The Philosophical Investigations he makes explicit his descendental move, declaring that "the preconceived idea of crystalline purity can only be removed by turning our whole examination around. (One might say: the axis of reference of our examination must be rotated, but about the fixed point of our real need)" (PI,\#108). The rotation, like James's change of philosophy's center of gravity, recovers the horizontal surface of the earth. Pragmatists and Wittgenstein are skeptical of the proposition that all experience is a mode of knowing. The correlatives of this rationalism-the Cartesian distinctions that favor mind over body, inner over outer, private over public-acquired the status of orthodoxy, what goes without saying. Wittgenstein in his later work begins not with reason or reflection but instead construes philosophy as an activity, "a matter of coming to grips with our own animality" in the words of a commentator. ${ }^{45}$ But rather than make the familiar modernist (and romantic) move to oppose "something animal" to the rational, Wittgenstein makes a crucial reorientation that alters our understanding of rationality: "Knowledge' and 'certainty' belong to two different categories" (OC, \#359, \#308). When man acts with "comfortable" certainty he is to be regarded, says Wittgenstein, as a "creature in a primitive state" (\#475).

For a student of pragmatism, this last phrase recalls Dewey's emphasis on man as a "live creature" rather than primarily a cogitating one. The intellectualist assumption, Dewey declared in 1925, "goes contrary to the facts of what is primarily experienced. For things are objects to be treated, used, acted upon and with, enjoyed and endured, even more than things to be known. They are things had before they are things cognized." ${ }^{46}$ For Wittgenstein, certainty of belief is had before cognized; in his words, certainty is "beyond being justified or unjustified" but is "something animal" ( $O C$, \#359). That is, we do not stand in an epistemological relation to basic beliefs_-"I have a body," "the world exists," "here is a hand." These function not as propositions (knowledge claims) but as "hinges" (\#341), meaning they are immune from skeptical doubt, not subject to judgment, but rather "stand fast" for us-are silently taken for granted-and hence acted upon without reflection and with instinctive trust ("I do not get my picture of the world by satisfying myself of its correctness") ("to think one is obeying a rule is not to obey a rule"); they constitute our "inherited background" against which we distinguish true and false (OC, \#94; PI, \#202). Our blind trust makes our basic beliefs "stand fast for us" without any need to interrogate their grounds. "They are there-like our life" (OC, \#559). This is not to deny that there is also a certainty that is justified, that we come to after reasoning and observing. But this is not Wittgenstein's concern. His stress on the nonepistemic nature of certainty blunts the edge of skepticism

“Don't think, but look!": W. G. Sebald, Wittgenstein, and Cosmopolitan Poverty

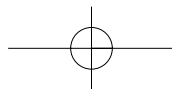


by denying space for its opening wedge-the question "how do you know?" with its built-in infinite regress. Once we have been trained, that is, have internalized the rules that govern thought and speech, giving grounds naturally comes to an end: "It is our acting, which lies at the bottom of the language game" (OC, \#204).

The emphasis on acting, basic as well to pragmatism ("true thoughts" are "instruments of action"), eventually is betrayed by William James in the zeal of his flight from the "refinements" of Cartesianism. James proudly lets his pragmatism go to the dogs: the pragmatist "world would not be respectable philosophically. It is a . . d dog without a collar in the eyes of most professors," and to preside over it he invokes another dog. Of the "radical pragmatist," James says: "If he had to live in a tub like Diogenes he wouldn't mind at all if the hoops were loose and the staves let in the sun" (WJ, 600-1). Announcing kinship with Diogenes licenses James's descent to the horizontal. Scorning the "refinement" of the classroom, the pragmatist takes to the "street" and delights in finding it "multitudinous beyond imagination, tangled, muddy, painful and perplexed" (WJ, 495). His next book, A Pluralistic Universe (1909), finds James diving into "the middle of experience, in the very thick of its sand and gravel," looking "downward and not up." Getting down and dirty might help us break free of the "vicious intellectualism" imbibed from Plato, the assumption that "reality consists of essences, not of appearances" ( WJ, 756).

Wittgenstein would have found congenial the (downward) drift of James's thinking here; congenial but also alarming: for whereas James puts philosophy "flat on its belly" and leaves us helpless infants, Wittgenstein resists this too literal horizontality: he wants intimacy with the "rough ground" but also to "to walk" on it. He will "regard man here as an animal," that is, one who moves confidently and spontaneously in the world, imbued with a "peace" unafflicted by doubt about what is certain. In sum: with A Pluralistic Universe, James's extended flight from intellectualism seems to reach an impasse of immobility, as he concludes plaintively that he must "deafen" us "to talk" and let "life" teach the lesson. Wittgenstein in effect supplies the teaching: "my life shows" that I am certain. In other words, James's impasse exposes the limits of his anti-intellectualism. Wittgenstein would likely say that his impasse was inevitable, built in to James's commitment to capital P Pragmatism even if practiced as a small $p$ philosophy. James, in short, was committed to a Weltanschauung (as Wittgenstein noted of pragmatism in On Certainty), and all Weltanschauungs imprison, even anti-essentialist ones. With no interest in constructing overarching frameworks, Wittgenstein proves to be more rigorous than pragmatists in his rejection of intellectualism and its breeding of skeptical doubt. So Wittgenstein edges James and Dewey out for the title: "the greatest anti-intellectual intellectual of the twentieth-century." 47

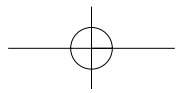


But if we go back in time, Diogenes is the clear victor. In his triumph over abstraction, Diogenes let his body, rather than any doctrine, enact his cultural critique; he left no writing behind and all we have are anecdotes. Loafing was crucial to Diogenes' way of life, whose most notorious moment occurred as he lazily sunned himself on his back when the young Alexander of Macedonia (the future Alexander the Great), intrigued by Diogenes' fame, came to ask the philosopher what wish he might grant him. "Stop blocking my sun!" Diogenes barked. Diogenes' rude riposte to Alexander no doubt delighted William James not least because it speaks directly to what in The Varieties of Religious Experience he calls "the value of saintliness" as freedom from desire and power. He seeks to "rehabilitate" this saintly virtue as a live moral option in contemporary life. Asceticism, James urges in Varieties, should become synonymous with the "strenuous life" reconceived as an embrace of poverty rather than "wealth-getting." "We have grown literally afraid to be poor. We despise anyone who elects to be poor in order to simplify and save his inner life. ... We have lost the power even of imagining what the ancient idealization of poverty could have meant," and then James goes on to enumerate its meanings as if he is describing Diogenes: "The liberation from material attachments, the unbribed soul, the manlier indifference, the paying our way by what we are or do and not by what we have, the right to fling away our life at any moment irresponsibly" ( $W J, 333){ }^{48}$

One enthusiastic reader of Varieties seemed to take James's words to heart, for in 1919 he disinherited himself from his share of a large family fortune and for the rest of his life lived as an ascetic. In 1912 Ludwig Wittgenstein had written to Bertrand Russell about Varieties: "This book does me a lot of good. I don't mean to say that I will be a saint soon, but I am not sure that it does not improve me a little in a way in which I would like to improve very much." ${ }^{49}$ Saintliness fascinated Wittgenstein and on at least one occasion he admitted that he sought moral perfection. ${ }^{50}$ He was devoted to rigorous selfexamination and confession, and at times in his life he thought of joining a monastery and becoming a monk. Unsparing personal self-scrutiny-what he called "the terribly hard work" of dismantling "the edifice of your pride"-is required for both personal and philosophical honesty: "If anyone is unwilling to descend into himself, because this is too painful, he will remain superficial in his writing." ${ }^{51}$ What makes William James a good philosopher, Wittgenstein remarked to a friend, is that "he was a real human being." ${ }^{2}$ This was no small achievement. For as Wittgenstein put it: "What is the good of philosophy if it does not make me a better human being?" 53 To make a "better human being" requires philosophy to be better. To start, one must "imperturbably bear witness to the spirit" of poverty, to borrow James's words (WJ, 334), a fidelity that requires not only dismantling personal but also philosophic pride.

“Don't think, but look!": W. G. Sebald, Wittgenstein, and Cosmopolitan Poverty 
Philosophic pride, often the result of aping positivist science, needs to be stripped away; only then one might gain respect for what is on the surface. To accept "thinking" on the model of science, as the seeking of theories, essences, principles, definition, is to accept the "craving for generality" that he finds synonymous with "the contemptuous attitude toward the particular case." That contempt keeps one's gaze aloof, disembodied, instrumental. ${ }^{54} \mathrm{He}$ offers his own work as remarks "on the natural history of human beings . . observations which no one has doubted, but which have escaped remark only because they are always before our eyes" (PI, \#415). To cure us of blindness to what is right in front of our eyes, Wittgenstein urges that we "Don't think, but look!" So he replies to his imagined interlocutor who has demanded he name the common essence that all games possess. The philosopher answers: "Don't say: 'There must be something common, or they would not be called "games"-but look and see whether there is anything common to all" (PI, \#66). ${ }^{55}$ Look, for example, at board games with their multifarious relationships, at card games, at Olympic games. If we keep looking what we see is a network of "overlapping and crisscrossing" that coheres as a "family resemblance." The result of looking, then, is to bring the notion of "game" down to earth from its metaphysical to its everyday use (\#116). Instead of pinpointing a hard and fast definition of games, we discover that blurriness of definition can have its uses, indeed is how in ordinary circumstances we use the notion of "game." "Inexact ... does not mean "unusable" (\#88).

Respect for blurriness is necessary for the kind of clarity Wittgenstein and Sebald seek, and it requires patient looking. The imperative "Don't think, but look!" can serve as the motto of a pivotal moment in Sebald's oeuvre, the scene near the opening of The Rings of Saturn where he discusses Rembrandt's Anatomy Lesson of Dr. Tulp. Sebald's narrator has been tracking the career of the Renaissance doctor and writer Thomas Browne, including his life as a medical student in Holland at the very time-January 1632 — when the yearly public dissection of a corpse took place in Amsterdam. "The spectacle, presented before a paying public drawn from the upper classes, was no doubt a demonstration of the undaunted investigative zeal in the new sciences; but it also represented (though this surely would have been refuted) the archaic ritual of dismembering a corpse, of harrowing the flesh of the delinquent even beyond death" $(R S, 12)$. The tension the narrator adumbrates here-the ritual archaic violence barely contained by the pomp of the scientific occasionis resolved by his observation that Rembrandt has directed the gazes of the doctors huddled around the displayed corpse to fall on the open anatomical atlas and not the body. In the atlas, "the appalling physical facts are reduced to a diagram, a schematic plan of the human being, such as envisaged by the enthusiastic amateur anatomist René Descartes, who was also, so it is said, present that January morning. . . . In his philosophical investigations, which form

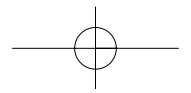


one of the principal chapters in the history of subjection, Descartes teaches that one should disregard the flesh, which is beyond our comprehension, and attend to the machine within, to what can be fully understood, be made wholly useful for work" $(R S, 13)$. Rembrandt, as if in protest of the medical establishment's exclusion of the displayed body (a violence of suppression that matches the original violence inflicted upon the corpse) identifies with "the victim" and not the guild that gave him his commission: the painter's "gaze alone is free of Cartesian rigidity. He alone sees that greenish annihilated body, and he alone sees the shadow in the half-open mouth and over the dead man's eyes" (RS, 17).

This passage from his third novel (1995) resonates as a defining moment in his corpus, for it dramatizes Sebald's own aesthetic stance as implicitly emerging from a choice between excluding or including the body, between an Enlightenment rationalist imperative of knowledge as subjugation and abstraction, and an alternative that renders the aesthetic as counterstatement to such mastery-as sensuous apprehension of the particular freed from this ritual of intellectual subjection. In other words, what Sebald's choice recovers and rehearses is the root meaning of aesthetic (as explicated by Baumgarten in 1750) as the supplement to cognition of clear and distinct ideas that we apprehend with our superior faculty - the mind. The aesthetic posits another, "lower" form of cognition, derived from "experience" where reigns "confused" perception-of sensation, passion, feeling-received through our "inferior faculty" of sense. ${ }^{56}$ In rejecting the reduction of the body to a mere teaching instrument for acquiring exact knowledge, Sebald's aesthetic perception has a political content, for in choosing to side with Rembrandt's loyalty to the victim, in this case the corpse, he affiliates with the forgotten histories of the helpless, the marginalized, and the terminally eccentric, a bond that runs through all of Sebald's books. This advocacy, a standard postmodern alignment, protests the brutality of instrumental agencies of power, but also marks, perhaps, a limit of Sebald's imagination. Here he seems obliged to put in evidence his impeccable postmodernist (that is, anti-Enlightenment) ethical credentials. But his imagination's audacious working upon history fortunately overshadows this programmatic quality.

The imperative to "look!" at the fleshly body and "appalling physical facts" forecasts precisely the demand of Sebald's most controversial work: Luftkreig und Literatur (The Air War and Literature), translated in English as On the Natural History of Destruction $(1999 ; 2003)$. His concern is the numbing silence in the aftermath of the 1945 Allied bombing of 131 German towns and cities that killed more than six hundred thousand civilians and left more than seven million homeless. The "images of this horrifying chapter in our history have never really crossed the threshold of the national consciousness" and have left "scarcely a trace of pain," claims that many of his readers found exaggerated. ${ }^{57}$

“Don't think, but look!": W. G. Sebald, Wittgenstein, and Cosmopolitan Poverty

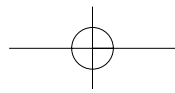


Psychic survival seemed to depend on insulating oneself from the reality of the horror; hence the development of an "extraordinary faculty for self-anesthesia" $(\mathrm{NH}, 11)$. Sebald is obsessed by his nation's abdication of vision, its exclusion of bodies, its balked looking. He comments on the recollections of a Swedish journalist in 1946 on a train riding past the devastated city of Hamburg: "The train was crammed full . . . but no one looked out of the windows, and he was identified as a foreigner himself because he looked out" $(\mathrm{NH}, 30)$. In the tradition of Diogenes the exile, Sebald the cosmopolitan "foreigner" courts outrage as he insists on looking and on showing what has been kept hidden. ${ }^{58}$

The traumatized suppression of trauma in postwar Germany, the freezing of affect in the face of unbearable horror, was manifested in a brisk setting to work, a "declaration of a new beginning . . . the first stage of a brave new world." It was as if an entire nation had imbibed the spirit of the Cartesian cogito by erasing the past, bracketing custom and tradition, leaving the self unfettered. This tabula rasa-a national psyche become "the almost perfectly functioning mechanism of repression"-was required for the swift postwar economic recovery from the ashes $(\mathrm{NH}, 12)$. Sebald figures this repression, this "self-imposed silence," as a "scandalous deficiency" that casts a "shadow" over him: "I had grown up with the feeling that something was being kept from me." This primal deprivation or poverty comprises "those horrors" he did not experience, since Sebald was a year old when the war ended ( $\mathrm{NH}$, 70-71). The silence that blankets family discussion, historical treatises and postwar German literature inspired the young Sebald to repair this deficit; he reads ravenously "to glean more information about the monstrous events in the background" of his own life $(N H, 70)$. His pursuit of learning leads him beyond the homeland to study in French-speaking Switzerland before becoming a permanent émigré as a Professor of German literature at the University of East Anglia. Sebaldian cosmopolitan plenitude is nourished in the poverty of his belatedness.

For Sebald, a sense of being haunted and impoverished is the very condition of his cosmopolitan porous self whose exile from the raw horror of war (and then his later, elected exile from Germany) has compensated him with a sympathetic imagination that banishes the hidden and is open to vertiginous incursions and "curious confusion" that violate normal temporal-spatial boundaries and take a bodily toll $(A, 6)$. Emptied of interiority, tramping a perpetual journey, Sebald's labile self is one of impulsive attunements, "instant conductors" (to borrow a phrase from another perpetual wanderer, Whitman). The urgent force of affinity and empathy makes "time, space, distance avail not" (as Whitman writes in "Crossing Brooklyn Ferry"); this power is glimpsed in Sebald's first literary work, the long poem After Nature (1988, 2002). Its first section dwells on the empathic suffering of the Renaissance

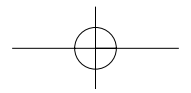


painter Matthias Grünewald. After learning news of the slaughter of peasants "he ceased to leave his house. / Yet he could hear the gouging out / of eyes that long continued / between Lake Constance and / the Thuringian Forest. / For weeks at that time he wore / a dark bandage over his face." 59

Here the reach of aesthetic sympathy, which turns imagination auditory so it hears what it never witnessed-eyes gouged out-entails a mimetic response, distilled in the "bandage" Grünewald dons. Repeated later, "bandage" becomes the bridge linking this passage to another act of empathic identification that obliterates distance. This later passage portrays the primal moment of aesthetic looking in Sebald's childhood. Like Grünewald, he confronts disaster from afar but by means of an intuitive mimesis attains imaginative intimacy with the victims: "I grew up, / despite the dreadful course / of events elsewhere, on the northern / edge of the Alps, so it seems / to me now, without any / idea of destruction. But the habit / of often falling down in the street and / often sitting with bandaged hands / by the open window ... waiting for the / pain to subside and for hours / doing nothing but looking out, / early on induced me to imagine / a silent catastrophe that occurs / almost unperceived" $(A N, 89)$. The "looking out" of aesthetic vision is precipitated by a literal fall, a descent to the horizontal animal level that at once brings bodily pain and a sharpened attentiveness.

A similar effort to bring history down to earth informs his "natural history of destruction" of 1945 Germany. But some hear in the phrase "natural history" a "traditional metaphysics of nature" that evades history and politics by conceiving "war as a revolt of nature." ${ }^{60}$ Yet Sebald's "natural history" in fact plunges to the microlevel of politically unleashed chaos: "the aimless wanderings of millions of homeless people"-the displaced, dazed, and drifting survivors of a Hamburg now become a "necropolis"- testify not only to a historic crisis of regression but a crisis in history whereby a population "torn from its civil existence and its history [is] thrown back to the evolutionary stage of nomadic gatherers" $(\mathrm{NH}, 36)$. With the Royal Air Force alone dropping a million tons of bombs, "what we have thought for so long to be our autonomous history" slides "back into the history of nature" $(\mathrm{NH}, 66)$. Acknowledging this "change in the natural order of the cities" and assessing its consequences is the responsibility of a natural history of destruction (34). Sebald's consistent aim is to bear witness to a double upheaval: when "the natural order of the cities" is toppled, so is the hierarchical relation of man and animal; revealed anew is man's embeddedness in a natural history shared with all species.

Recognition of this commonality was particularly difficult for Nazis, Sebald surmises, given that the purity mania of their Übermensch ideology was pledged to "clean and sanitize all Europe." But now, after the firestorms of Hamburg and elsewhere, with dismembered corpses redolent of stench and decay lining the streets, new species ruled the cities: "slippery finger-length

“Don't think, but look!": W. G. Sebald, Wittgenstein, and Cosmopolitan Poverty

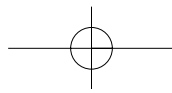


maggots" and rats and flies grown to sizes never seen before $(N H, 35)$. Europe's master race "now had to contend with the rising fear that they themselves were the rat people" $(\mathrm{NH}, 34)$. Some of the grimmest pages of Sebald's natural history set before us the animal suffering amid the bombing of the Berlin zoo. Agonized deer and monkeys and reptiles fled into the city to mix with human wanderers; corpses of elephants had to be cut up to be cleared away by men "crawling around inside the ribcages," "burrowing through mountains of entrails" $(\mathrm{NH}, 92)$. Sebald remarks: "These images of horror fill us with particular revulsion because they go beyond those routine accounts of human suffering that are to some extent precensored" $(\mathrm{NH}, 92)$.

To deaden affect and impose the blindness of routine: this is the ideological work of "the precensored" as it hollows out the capacity for looking. The "precensored" at its most brilliantly demonic inspires its audacious undoing in a remarkable episode toward the end of Austerlitz that pushes "family resemblance" and "ragged" looking to their limits by pushing them into contexts of historical trauma. In so doing, the effort to "desublime," to bring down projects of purification, will come to involve a related effort, to "defamiliarize," that also makes abstraction the enemy; for to "defamiliarize" is to disrupt habit's numbing of perception. ${ }^{61}$ The "precensored" I have in mind in Austerlitz takes the form of the "vast cleaning-up program" accomplished by the commanders of Theresienstadt, Hitler's "model ghetto" $(A, 242)$. The Nazi imposing of refinement, here not the philosophical regime of metaphysical abstractions but a literal purification, sparks, in turn, a counter- assault on transparency that unravels the intelligible, as the act of looking becomes inseparable from a magnifying and distorting of vision and its objects.

Mainly a collection point for transport of the elderly and ill to Auschwitz, Theresienstadt was the only camp visited by the International Red Cross. It passed inspection with flying colors thanks to the Nazi "improvements campaign" that transformed bloody sites of filth, disease, and stacked corpses into an immaculate thriving town replete with concert hall, theater, coffeehouse, haberdashery, and convalescent home. This "Potemkin village," modeled to "suggest the agreeable atmosphere of a resort," enters into Austerlitz as part of the title character's quest to find his lost mother, whom he believes had spent time in the camp on the way to Auschwitz $(A, 243)$. At last delving into Nazi history, which his "avoidance system had kept from" him "for so long," Austerlitz overcomes his own precensoring impulse when he learns that the commandants of the camp had made a film, after the Red Cross visit, complete with a sound track of Jewish folk music. "I kept thinking," says Austerlitz, "if only the film could be found I might perhaps be able to see or gain some inkling of what it was really like," and he imagines recognizing his mother in the film $(A, 245)$.

When by luck he obtains a copy of the film of Theresienstadt, it turns out to be a mere fourteen-minute highlight reel, only a "patchwork of scenes"

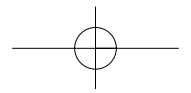


with no trace of his mother. But Austerlitz is determined to keep looking, and this requires that he disrupt the smooth surface of the "precensored." So he has a slow-motion copy made, one that lasts a whole hour and brings previously shadowy figures and objects into view. The slow-motion film in effect splatters death over the "seamless" sanitizing sham the Nazis had devised. For instance, a "merry polka" in the first version has now "become a funeral march dragging along at a grotesquely sluggish pace." Another piece of music "moved in a kind of subterranean world, through the most nightmarish depths . . . to which no human voice has ever descended." A Nazi's "highpitched strenuous tones" are now heard as a "menacing growl" ( $A, 249-50)$. Like Sebald's challenge in The Natural History of Destruction to the "faculty for self-anesthesia" that facilitates the production of a sanitized postwar German "normality," Austerlitz tampers with the Nazi's filmic memorial to coercive normalization at Theresienstadt.

In short, both Sebald and Austerlitz "defamiliarize" officially sanctioned reality so as to revive what the Nazi regime has smothered in the simulacralthe capacity for looking and hearing. To recall that Austerlitz's looking is literally a search for family resemblance is to recall Wittgenstein's warning against the pursuit of explanation-the rush to dig beneath in search of essence or origin or causation-which dismisses what is in front of our eyes. The "blurred edges" we find in looking for family resemblances, says Wittgenstein, are "often exactly what we need" $(P I, 71)$. Ragged edges, intolerable to instrumental thinking, proliferate in the film where, as the deceiving artifice melts away, the slowness acts to fasten our attention to the magnified, grainy imagery, as, analogously, Austerlitz, with his poor knowledge of German, "unraveled syllable by syllable" a massive history of the camp $(A, 233)$. Obliterating transparency, the slow-motion film enacts Sebald's own version of "don't think, but look!" by in effect literalizing the classic formulation of Russian formalist Victor Shklovsky, who in 1917 describes defamiliarization as challenging affective and perceptual numbness by "increas[ing] the difficulty and length of perception." Only this can resist the blinding and devouring "process of habitualization" and thereby make one "feel things, to make the stone stony." ${ }^{62}$ In slowing down the film, Sebald/Austerlitz is doing nothing less than making it a work of art. Says Shklovsky: "A work is created 'artistically' so that its perception is impeded and the greatest possible effect is produced through the slowness of the perception" $(S, 225)$. The slow-motion film elongates perception to eviscerate cognitive security, as our faith in the appearance of contentment in the people depicted at normal speed gives way to disorientation at the slow-motion blurring of the contours of bodies; dissolved at the edges, they turn the film image into "patterns of bright white sprinkled with black" on "damaged sections of the tape," distortions of perception that bear witness to the violence the film at once conceals and

“Don't think, but look!": W. G. Sebald, Wittgenstein, and Cosmopolitan Poverty

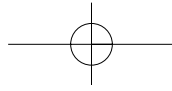


exposes. Sebald makes our witnessing visceral by reproducing on a double page the damaged film stock and sets us upon the depthless disintegrative visual field. In the exposure of sheer material surface "nothing is hidden" (to borrow Wittgenstein's phrase).

Yet on another level something does remain hidden: his mother remains unfound and neither the short nor the slow film reveals "what it was really like" in Theresienstadt to an Austerlitz eager for evidence. ${ }^{63}$ But when read as an allegory of defiant aesthetic seeing, the slow film recovers the capacity for looking: its defamiliarizing shock tactics unfreeze what the "precensored" blocks and bring us into the ambit of terror. The slow film grotesquely transmogrifies what was itself a grotesque transmogrification-the "improvements campaign"- to reveal the deathliness at the edges of the sunny spruceness of the model ghetto. And this deathliness is formally embodied in the hideous slowness, which produces the material corrosion of the film image and thereby corrodes our own vision, turning looking into an ordeal that makes us see. Or, to borrow Shklovsky's words, makes the stone stony.

To escape the "precensored" and to look at the poverty and darkness bequeathed (and suppressed) to his generation is the imperative of Sebald's aesthetic vision. The imperative requires remaining attentive to the "appalling physical fact" that will not be reduced, like the corpse in The Anatomy Lesson, to a schematic diagram, or to props in a Nazi charade at Theresienstadt, or to "silence" and "instinctive looking away" in 1945 Hamburg (31). In each instance Sebald recovers the tormented body of experience, culminating in the chaos of the Berlin Zoo where men are "crawling around inside the ribcages" opening up animal interiority, turning the insides out into public space. "These images of horror fill us with particular revulsion," as Sebald noted, and they also express his rage to break through postwar German numbness and repression, a rage against abstraction that requires he obliterate any notion of the hidden and thrust in front of us imagery that makes looking viscerally repugnant. Eschewing primitivist liberation while enacting a "culture crime of desublimation," Sebald brings together Diogenes' rudeness, his freedom of deracination and scandalous dissolution of the private, with Wittgenstein's command that we stay on the "rough ground" and engage in desublimed looking. "I don't try to make you believe something you don't believe, but to make you do something you won't do," says Wittgenstein. ${ }^{64}$ The doing of looking - the activity Wittgenstein and Sebald perform and demand of their readers - asks us to "head straight for what is concrete" and not be tempted to climb ladders or armor ourselves in the pride of rational refinement. Instead, accept that "the place I really have to get to is a place I must already be at now" ( $C V, 6-7)$. Already and always in a specific place and grappling with specific circumstances, we are embedded in the teeming multiplicity of contexts- "the whole hurly-burly of human actions" - that

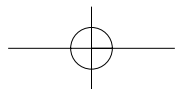


comprise the ordinary, the everyday $(Z, \# 567)$. Rather than elaborating theses or plots, antiphilosopher and antinovelist are absorbed in tracking the "intricate design" and "complex patterns" of cases and contexts $(R S, 283)$. Attentive to webs of connection, overlap, and crisscross- the weave of family resemblance-they make desublimed looking part of our natural history, the "walking, eating, drinking, playing" we share with other animals (PI, 25). "Language-I want to say-is a refinement, "in the beginning was the deed" $(C V, 31)$. With astonishing wordless precision, Sebald, at the start of Austerlitz, enacts these realignments of animal and human, deed and language, by presenting us with four pairs of eyes. We confront bat and owl, painter and philosopher, their unsettling gazes of unblinking opacity, neither contemplative nor introspective, challenging us to look.

\section{Notes}

For helpful responses to earlier drafts of this essay, I thank Charles Altieri, Sara Blair, Sharon Cameron, Gregg Crane, Joan Richardson, and audiences at Rutgers and McGill.

1. W. G. Sebald, untitled poem, in Unrecounted: 33 Poems, lithographs by Jan Peter Tripp, trans. Michael Hamburger (New York, 2004), 57.

2. W. G. Sebald, Austerlitz, trans. Anthea Bell (New York, 2001), 136, hereafter A.

3. W. G. Sebald, The Rings of Saturn, trans. Michael Hulse (London, 1998), 187, hereafter $R S$.

4. Ludwig Wittgenstein, Philosophical Investigations, 3rd ed., trans. G. E. M. Anscombe (New York, 1975), \#67, hereafter PI.

5. Sebald, quoted in Eric Homberger, "W. G. Sebald," Guardian, 17 December 2001.

6. See Eric Santner, On Creaturely Life: Rilke, Benjamin, Sebald (Chicago, 2007), xix. Melancholy, allegory, the baroque, natural history, creatureliness, mythic violence, redemption: these are some of the Benjaminian terms that organize Santner's discussion of Sebald. The most extended discussion of Wittgenstein and Sebald is chap. 3 of Martin Klebes, Wittgenstein's Novels (New York, 2006). An essay that includes some discussion of the philosopher and novelist is Bettina Mosbach, "Superimposition as a Narrative Strategy in Austerlitz," in Searching for Sebald: Photography After Sebald, ed. Lise Patt (Los Angeles, 2007), 390-407.

7. Ludwig Wittgenstein, On Certainty, trans. Denis Paul and G. E. M. Anscombe (New York, 1972), \#475, hereafter $O C$.

8. Sebald mentioned the draft of the Wittgenstein film script to James Wood in an interview in 1997 published in Brick 69 (Spring 2002): 95.

9. W. G. Sebald, The Emigrants, trans. Michael Hulse (New York, 1996), 166-67.

10. Theodor Adorno, Minima Moralia, trans. E. F. N. Jephcott (London, 1978), 39.

11. Theodor Adorno, Hegel: Three Studies, trans. Shierry Nicholsen (Cambridge, 1993), 123, 140-142. Adorno discusses his "ideal of nonargumentative thought" in relation to Hegel's Phenomenology, but the later Wittgenstein, of the Investigations,

“Don't think, but look!": W. G. Sebald, Wittgenstein, and Cosmopolitan Poverty

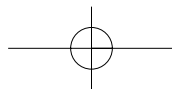


is also famous for, in effect, pursuing this ideal in his own way as he strips philosophy of reliance on doctrine, theses, or theories.

12. Russell Goodman carefully discusses James and Wittgenstein in Wittgenstein and William James (Cambridge, 2002), and James Edwards offers a cogent account of Wittgenstein's relation to pragmatism in Ethics Without Philosophy (Gainesville, 1982), 225-29.

13. William James, Writings, 1902-1910 (New York, 1992), 496, hereafter WJ.

14. If one current of modernism, Joyce, Eliot, and Pound, for example, produced the heterocosm-artifacts of formal experimentation discontinuous with lifeanother current sought a reinstatement of the living body, even, at an extreme, "to pit the body against the eye," the latter understood as the instrument of the policing gaze. Martin Jay has mapped the critique of modernity's scopic regime in French painting (starting with Cézanne) but also in surrealism, phenomenology, existentialism, a critique that paves the way for the rampant anti-ocularism found in masters of postmodernism-Lacan, Althusser, Barthes, Foucault, Lyotard, Debord. And Jay notes that the Cartesian gaze is, however unfairly, "time and again" the source these thinkers name of the abhorrent fetish of the visual; Martin Jay, Downcast Eyes (Berkeley, 1993), 161, 589.

15. Rosalind Krauss, "Antivision," October 36 (Spring 1986): 147, 153.

16. Rosalind Krauss, "Greenberg on Pollock," in Pollock and After, ed. Francis Frascina, (New York, 2000), 362-63. In her aptly titled Eyesight Alone: Clement Greenberg's Modernism and the Bureaucratization of the Senses (Chicago, 2005) Caroline Jones also remarks the romanticism of Krauss's Pollock (258) while implicitly in sympathy with her rejection of Greenberg's sponsorship of modernity's segmented, hygienic, disembodied sensorium (alluded to in Jones's subtitle).

17. Philip Roth, Zuckerman Bound (New York, 1985), 567.

18. Pollock's squatting has inspired a range of artists to explore horizontality. Among those who are arguably referencing Pollock: Yves Klein's Anthropometries (1960) (nude female models, whom he dubbed "living brushes," smeared themselves with blue paint and imprinted their bodies on canvas and paper that either hung on the wall or was on the floor) deploys horizontality but as a deliberate critique of gestural abstraction, since Klein himself remains a detached, immaculate orchestrator, an anti-Pollock. Another descendant of Pollock reduces him to absurdity. Paul McCarthy, in Face-Painting-Floor, White Line (1972), mocks Pollock's desubliming by going him one better-or lower: McCarthy films himself crawling across the floor of his studio, arms and body confined to a straightjacket, pushing a can of white paint with his head as he makes a white line. A particularly creative use of Pollock's lowness is that of the painter and film critic Manny Farber, an admirer and friend of Pollock's who, in a 1945 essay on the painter, drew attention to how his work explores possibilities of "horizontal design." Fittingly, Farber's own early paintings were gestural abstractions created on the floor. And this horizontality informs Farber's film aesthetic, his famous advocacy of what he calls "termite art"-mainly film noir but also early Godard-against the middlebrow pomposity of "white-elephant art." "The important trait of termite-fungus-centipede art," writes Farber, "is an ambulatory creation which is an act both of observing and being in the world, a journeying in which the artist seems to be ingesting both the material of his art and the outside world through a horizontal coverage" (10). Both Sebald and Wittgenstein would find this aesthetic compatible with their own commitment to perpetual observing and journeying; Manny Farber, Negative Space (New York, 1998).

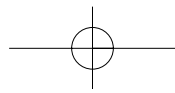


19. Stanley Cavell, This New Yet Unapproachable America (Albuquerque, 1989), 42, 44.

20. Cavell in this context associates the vertical and biological, the conventional and horizontal.

21. Ludwig Wittgenstein, Zettel, trans. G. E. M. Anscombe (Berkeley, 1967), \#455, hereafter $Z$.

22. Ludwig Wittgenstein, Culture and Value, trans. Peter Winch (Chicago, 1984), 28, hereafter $C V$.

23. Judith Genova, Wittgenstein: A Way of Seeing (New York, 1995), 36.

24. Benjamin says of melancholy's downward gaze: "Everything saturnine points down into the depths of the earth" (quoted in Santner, On Creaturely Life, 20).

25. This page is reproduced from the Penguin edition. In a review, Michael Andre Bernstein claims that all four of the images are not photographs but Tripp's lithographs, what the painter calls his "eye-landscapes." While plausible, Bernstein is the only commentator I know who ascribes these images to Tripp; Michael Andre Bernstein, "The Sorrow Reflex," New Republic, July 25, 2005, 36.

26. Raymond Geuss, Public Goods, Private Goods (Princeton, 2001), 26.

27. Frank Kermode usefully links Wittgenstein's rejection of explanation in favor of looking to Ferdinand de Saussure's stress on the synchronic over the diachronic in Course in General Linguistics (1915); "Modernism, Postmodernism, and Explanation," in Prehistories of the Future, ed. E. Barkan and R. Bush (Stanford, 1995), 357-72.

28. Diogenes Laertius, Lives of Eminent Philosophers, trans. R. D. Hicks (Cambridge, MA, 2000), 2:41, hereafter $L$.

29. William James, Writings, 1878-1899 (New York, 1992), 164.

30. Commentary on Sebald and photography is already abundant; see Lise Patt's massive volume of essays Searching for Sebald.

31. "Urge to appear" and to display is Hannah Arendt's phrase as she evokes a phenomenology of "the value of the surface" as the reversal of metaphysical hierarchy; part one of her The Life of the Mind (New York, 1978), 29.

32. Pierre Hadot, Philosophy as a Way of Life, trans. Michael Chase (Blackwell, 1995), 265.

33. Pierre Hadot, What Is Ancient Philosophy? trans. Michael Chase (Cambridge, MA, 2002), 109. In his introduction to Philosophy as a Way of Life, Arnold Davidson points out the continuity of Hadot's early work on Wittgenstein and his later work on the ancients.

34. Martha Nussbaum, Cultivating Humanity (Cambridge, MA, 1998), 56.

35. Whereas Nussbaum portrays Diogenes as offering social critique, Raymond Geuss argues that Diogenes' project is "deeply unpolitical" because his quest for radical self-sufficiency refuses "the mutual dependence" that is a "precondition of politics." His cosmopolitanism, says Geuss, is "of a purely negative kind . . . the rejection of any concrete political engagement" (29). D'Alembert quoted in David Mazella, The Making of Modern Cynicism (Charlottesville, 2007) 112.

36. Philip Roth, Portnoy's Complaint (New York, 1970), 305.

37. Walter Harding, "Thoreau at the Boston Music Hall," Thoreau Society Bulletin 105 (Fall 1968): 7. Diogenes helped inspire the most famous moment of horizontality in the nineteenth century-Whitman's gravitational shift in 1855 in the famous opening lines of "Song of Myself": "I loafe and invite my soul, / I lean and loafe at my ease observing a spear of summer grass." Whitman in 1840 had noted that the bodily posture of leaning and loafing had a philosophical pedigree and saluted Diogenes: "He lived in a tub, and demeaned himself like a true child of the great loafer family"; Walt Whitman, Uncollected Poetry and Prose, ed.

“Don't think, but look!”: W. G. Sebald, Wittgenstein, and Cosmopolitan Poverty

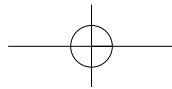


E. Holloway (New York, 1921), 44. The quotation is from "Sun-Down Papers," no. 9. David Mazella in The Making of Modern Cynicism (Charlottesville, 2007) provides a useful survey of Diogenes' influence on key figures in the eighteenth and nineteenth centuries. More recently, Diogenes has been appropriated for postmodernism by Peter Sloterdijk in Critique of Cynical Reason, trans. Michael Eldred (Minneapolis, 1987), 160-61. In 1984, Michel Foucault devoted some of his last lectures to parrhesia — the Greek tradition of truth-telling — and expressed kinship with what he called the Cynic inversion of the dominant Platonic notion of the exemplary philosophic life-a "metaphysics of the soul" founded on otherworldly rectitude and purity. Diogenes stands in jeering contrast, embodying, for Foucault, "life as the scandal of truth"; Thomas Flynn, "Foucault as Parrhesiast: His Last Course at the Collège de France," Philosophy and Social Criticism 12, nos. 2-3 (1987): 221.

38. Foucault quoted in Louis Sass, Madness and Modernism (New York, 1992), 246.

39. Frans de Waal, Primates and Philosophers: How Morality Evolved (Princeton, 2006), 10.

40. The refusal of what I am calling a "buried essence" model of authenticity coincides with Wittgenstein's rejection of the assumption of hiddenness as governing understanding of the mental and of privacy. Wittgenstein is unconcerned with notions of identity or authenticity, as Charles Altieri writes, and indeed posits freedom as resistance to all temptations "to hold out something important but hidden that somehow can be realized if we find some better or richer way of staging the self for ourselves. Wittgenstein invites us to suspect that we create ideals of hiddenness precisely in order then to dwell on concerns about how the subject can become more expressive and more 'authentic'”; "Cavell's Imperfect Perfectionism," Ordinary Language Criticism, ed. K. Dauber and W. Jost (Evanston, 2003), 216.

41. Roy Harris, Language, Saussure, and Wittgenstein (London, 1988), 31.

42. Ludwig Wittgenstein, Philosophical Occasions (Indianapolis, 1993), 119, 121.

43. On the continuity of embodied experience and thought in Dewey and James see Mark Johnson, The Meaning of the Body (Chicago, 2007), 121-24.

44. Frank Ankersmit's critique of Rorty is "Between Language and History: Rorty's Promised Land," Common Knowledge 6, no. 1 (Spring, 1997). See also Richard Shusterman, "Somatic Experience," chap. 6 of his Practicing Philosophy (New York, 1997). Forms of intellectualism pervade postmodernism: for instance, the belief in the ubiquity of textualism (Derrida), figurality (De Man), and interpretation (Fish). In an acute essay on Fish, Martin Stone notes that the superficial resemblance of Fish's critique of theory to Wittgenstein's suspicion of theory as the attempt to transcend practice should not block from view the deep divide between them: Fish sublimes interpretation into a metaphysical principle-as a "general condition of the possibility of anything meaning anything." For Wittgenstein, certainty and rule following are not, normally, things subject to doubt or reflection or interpretation. We interpret only in the face of real doubt, "not the mere notional possibility of doubt"; Martin Stone, "On the Old Saw: 'Every Reading of a Text Is an Interpretation': Some Remarks," in The Literary Wittgenstein, ed. J. Gibson and W. Huemer (New York, 2004), 186, 189.

45. Allan Janik, "Weininger and the Two Wittgensteins," in Wittgenstein and Weininger, ed. D. Stern and B. Szabados (Cambridge, 2004), 81.

46. John Dewey, Experience and Nature (La Salle, IL, 1929), 21.

47. This is how Louis Sass describes Wittgenstein in "Deep Disquietudes: Reflections on Wittgenstein as Anti-Philosopher," in J. Klagge, ed., Wittgenstein: Biography and

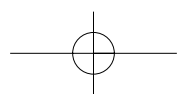


Philosophy (Cambridge, 2001), 102. But this caveat, from H. J. Glock, is useful: "Wittgenstein's anti-intellectualism should not be equated with irrationalism; it denies that reason and the intellect have the exalted place traditionally accorded them, but it often does so by rational argument." This applies to William James with equal validity; H. J. Glocke, "Wittgenstein and Reason," in Klagge, Wittgenstein, 197.

48. Without mentioning William James, Stanley Cavell has attended closely to the meanings of "poverty," finding in it a bridge from Emerson to Wittgenstein. See This New Yet Unapproachable America, 69-75.

49. Wittgenstein quoted in Goodman, Wittgenstein and William James, 41.

50. Ray Monk, Ludwig Wittgenstein: The Duty of Genius (New York, 1990), 369.

51. Wittgenstein quoted in ibid., 366.

52. Wittgenstein quoted in Goodman, Wittgenstein and William James, 37. One reason Wittgenstein may have been so taken with The Varieties of Religious Experience is that James's own act of self-descent informs the intimacy and compassion of his portrait of "the sick soul." His empathy derives from his own torment, decades earlier, from morbid indifference.

53. Wittgenstein quoted in James Conant, "Throwing Away the Top of the Ladder," Yale Review 79, no. 3 (1994): 364.

54. Ludwig Wittgenstein, The Blue and Brown Books (Malden, MA, 2006), 18.

55. In looking to see what is common to games, their family resemblance, one comes to certainty; it is justified through reasoning and observation; this mode of certainty is distinct from "hinge" or "animal" certainty. See Daniele Moyal-Sharrock, "Unravelling Certainty," in Readings of Wittgenstein's On Certainty, ed. D. MoyalSharrock and W. Brenner (London, 2005), 85.

56. Robert E. Norton, The Beautiful Soul: Aesthetic Morality in the Eighteenth Century (Ithaca, 1995), 85.

57. W. G. Sebald, On the Natural History of Destruction, trans. Anthea Bell (New York, 2003), 11, 4, hereafter $N H$.

58. In exposing what he regards as having been kept hidden both from himself and from postwar Germany, Sebald, it should be noted, tacitly relies on a surface/depth epistemology that does not accord with the Wittgensteinian ideal of de-sublimed looking that rules out the presumption of a buried essence.

59. W. G. Sebald, After Nature, trans. Michael Hamburger (New York, 2002), 35, hereafter $A N$.

60. Andreas Huyssen, Present Pasts: Urban Palimpsests and the Politics of Memory (Stanford, 2003), 150.

61. "Defamiliarization," alas, has itself become a term numbingly familiar in literary critical discourse. So it is worth noting what is little known: William James was a central influence on Shklovsky's reanimation of feeling and his somatic approach to literature. See Douglas Robinson, Estrangement and the Somatics of Literature: Tolstoy, Shklowsky, Brecht (Baltimore, 2008).

62. Victor Shklovsky, "Art as Technique," in Literary Aesthetics: A Reader, ed. A. Singer and A. Dunn (Oxford, 2000), 225, hereafter $S$.

63. For a reading of Austerlitz's "slow" film through a work Sebald admired, Roland Barthes's Camera Lucida, especially its emphasis on the mother image and child image, see Avi Kempinski, “'Quel Roman!': Sebald, Barthes, and the Pursuit of the Mother-Image," in Patt, Searching for Sebald.

64. Wittgenstein quoted in James Conant, "On Going the Bloody Hard Way in Philosophy," in The Possibilities of Sense, ed. J. Whittaker (London, 2002), 117.

“Don't think, but look!”: W. G. Sebald, Wittgenstein, and Cosmopolitan Poverty

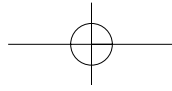

